\title{
DETERMINAN PRODUKTIVITAS PENGUSAHA RUMPUT LAUT PADA KETERBATASAN SALURAN PEMASARAN DI SENTRA PRODUKSI
}

\author{
Bahari \\ bahari.abdullah@yahoo.com \\ M. Arif Dirgantoro \\ Doddy Ismunandar Bahari \\ Universitas Haluoleo
}

\begin{abstract}
The research aimed to predict farmer's productivity level and to identify factors affecting productivity level in seaweeds farming in Muna District Southeast Sulawesi. To achieve that objectives, frontier cost function using OLS and MLE estimation method with Cobb-Douglas functional assupmtion was used. Eighty six respondents were selected by proportional random method. The results of cost function based on OLS and estimation based on MLE showed that variables of seed prices, transportation prices, labor price and amount of production had jointly significant affect. Research showed farmers achieved productivity levels between 80 to 99 percent with an average of 96 percent. Productivity level distribution was influenced significantly by seaweed sales price and dummy of marketing channels. Important policy implication was to increase amount of production to fulfill market demand can only be done by increasing scale because gap between average productivity of farmers with maximum productivity rate of allocation and best combination of inputs (best practiced farm) is fairly narrow. Increasing scale of seaweed farmers must been followed with reforming that involving the government to correct the marketing system of seaweed so gave better impact on the price at farm level that would increase farmers productivity.
\end{abstract}

Key words: Seaweed, stochastic frontier, economic efficiency.

\begin{abstract}
ABSTRAK
Penelitian bertujuan untuk menduga tingkat produktivitas pengusaha sekaligus mengidentifikasi faktor yang mempengaruhi tingkat produktivitas tersebut pada pengusahaan rumput laut di Kabupaten Muna Sulawesi Tenggara, yang sebelumnya menganalisis faktor yang berpengaruh terhadap fungsi biaya. Untuk mencapai tujuan tersebut maka digunakan fungsi biaya frontier dengan pendugaan metode OLS dan MLE dengan asumsi fungsional dalam bentuk Cobb-Douglas. Jumlah Responden 86 orang dipilih dengan menggunakan metode acak proporsional. Hasil penelitian fungsi biaya berdasarkan OLS menunjukkan keberpengaruhan harga bibit, harga transportasi, harga tenaga kerja dan jumlah produksi dan pendugaan berdasarkan MLE menunjukkan peubah secara bersamasama berpengaruh nyata. Penelitian menunjukkan pengusaha mencapai tingkat produktivitas antara 80 hingga 99 persen dengan rata-rata 96 persen. Sebaran tingkat produktivitas dipengaruhi secara nyata oleh harga jual rumput laut dan dummy saluran pemasaran. Implikasi kebijakan penting adalah peningkatan jumlah produksi untuk memenuhi permintaan pasaran hanya dapat dilakukan dengan peningkatan skala usaha sebab senjang antara tingkat produktivitas rata-rata pengusaha dengan tingkat produktivitas maksimum yakni alokasi dan kombinasi input yang terbaik (best practiced farm) cukup sempit. Peningkatan skala usaha harus diikuti dengan pembenahan yang melibatkan pemerintah untuk memperbaiki sistem pemasaran rumput laut agar memberikan dampak yang lebih baik terhadap harga di tingkat produsen yang pada akhirnya akan meningkatkan produktivitas pengusaha.
\end{abstract}

Kata kunci: Rumput Laut, frontier stokastik, efisiensi ekonomi 


\section{PENDAHULUAN}

Rumput Laut merupakan salah satu komoditas unggulan dalam sektor perikanan dan merupakan komoditas yang permintaannya semakin besar pada pasaran dunia, yakni berdasarkan data Kementerian Kelautan dan Perikanan (2010) dalam Karmila (2011) yang memprediksi pasar dunia olahan rumput laut meningkat sekitar $10 \%$ setiap tahun untuk keraginan, agaragar dan alginat untuk industri serta alginat untuk makanan mengalami peningkatan sebesar 7,5\% dan keraginan refine sebesar $5 \%$. Dengan demikian, maka pengusahaan rumput laut merupakan salah satu sektor usaha yang potensial mengingat permintaan pasar dunia yang semakin besar per tahunnya serta sebagai penyumbang Produk Domestik bruto (PDB) bagi peningkatan pertumbuhan ekonomi Indonesia dan penyedia lapangan pekerjaan yang mampu memberikan pendapatan yang layak bagi masyarakat yang membudidayakan rumput laut.

Rumput laut sebagai komoditas komersial terus berkembang pada beberapa lokasi di semua Kabupaten/Kota se Provinsi Sulawesi Tenggara. Luas areal budidaya rumput laut Provinsi Sulawesi Tenggara yang dikelola adalah $\pm 9.825,9$ Ha dengan volume produksi rumput laut kering sebesar $73.247,1$ ton. Potensi areal budidaya yang belum dikelola adalah 36.428,2 Ha yang diperkirakan dapat memproduksi rumput laut sebesar 262.073,5 ton/tahun. Daerah pengembangan berada dikabupaten Buton, Kabupaten Wakatobi, Kota Bau-Bau, Kabupaten Konawe, Kabupaten Kolaka, Kabupaten Muna dan yang paling sempit di Kota Kendari. Produktivitas rumput laut kering mencapai 1,3-3,84 ton/Ha, bila dikelola secara optimal maka total produksi rumput laut di Provinsi Sulawesi Tenggara diperkirakan mampu mencapai 335.320,7 ton setiap tahun.

Pengembangan usaha budidaya rumput laut selain dapat memberikan kontribusi bagi pertumbuhan PDB sektor perika- nan dan memenuhi kebutuhan masyarakat Indonesia dan Dunia juga mampu dikembangkan untuk mencapai tujuan utama dari pembangunan ekonomi, yaitu meningkatkan jumlah dan jenis peluang kerja untuk masyarakat daerah agar kesejahteraan masyarakat lebih merata.

Meskipun dari segi permintaan mendukung namun usaha budidaya rumput laut yang banyak dilakukan oleh masyarakat sebagai suatu mata pencaharian tidak lepas dari kendala yang dihadapi. Kendala tersebut yakni masalah rendahnya pendapatan yang diterima pengusaha karena harga jual yang rendah serta berfluktuasi yang disebabkan oleh biaya transportasi yang besar karena jarak sentra produksi yang sangat terpencil. Selain itu posisi tawar pedagang yang masih rendah karena struktur pasar komoditas yang tertutup serta belum berfungsinya kelembagaan pada tingkat pro dusen serta ketidakseimbangan kebutuhan industri setempat dengan supply dari produsen. Rendahnya harga jual tersebut merupakan masalah sistemik yang dihadapi pengusaha yang membutuhkan waktu yang tidak cepat untuk mengatasinya. Salah satu opsi yang dapat dilakukan pengusaha dalam waktu singkat yang dapat meningkatkan pendapatannya adalah dengan usaha mencapai produktivitas maksimalnya. Besaran peningkatan pendapatan pengusaha tersebut tergantung dari sejauh mana"gap" antara tingkat produktivitas yang diraih pengusaha saat ini dengan produkti vitas maksimalnya. Dengan begitu, untuk menelaah tingkat produktivitas usaha budidaya rumput laut ini maka secara khusus studi ini bertujuan untuk (1) menganalisis faktor-faktor yang mempengaruhi biaya produksi usaha budidaya rumput laut, (2) menduga tingkat produktivitas yang saat ini telah diraih oleh pengusaha budidaya rumput laut, serta (3) mengidentifikasi faktor-faktor yang mempengaruhi tingkat produktivitas yang saat ini telah diraih oleh pengusaha rumput laut di Kabupaten Muna. 


\section{TINJAUAN TEORETIS}

Komoditas rumput laut merupakan komoditas yang juga seharusnya memperoleh prioritas lebih tinggi dalam pengembangannya sebab mempunyai merupakan salah satu komoditi yang mempunyai biaya sumber daya domestik lebih kecil dari satu (Clenia, 2008). Selain itu Rumput laut merupakan sumber produk alami yang menjanjikan karena ekstrak rumput laut menunjukkan aktivitas antioksidan tinggi (Premalatha, 2011). Rumput laut segar merupakan produk bernilai tinggi, karena dijual sebagai makanan ke restoran atau sebagai bahan baku untuk perusahaan kosmetik, dan industry biofuel (Dunning- ham dan Attack, 2011). Dari sisi sosial-ekonomi juga pengusahaan rumput laut dapat meningkatkan pendapatan rumah tangga (Kronen, 2010).

Kemampuan usaha pengusahaan rumput laut di Kabupaten Muna untuk memberikan kontribusi secara langsung terhadap pertumbuhan ekonomi dan kesejahteraan rumah tangga pengusaha rumput laut di daerah tersebut tergantung pada tingkat pendapatan yang dihasilkannya. Tingkat pendapatan usahatani disamping merupakan penentu utama kesejahteraan rumah tangga petani juga sebagai salah satu faktor penting yang mengkondisikan pertumbuhan ekonomi. Tingkat pendapatan usahatani tersebut tidak terlepas dari tingkat produktivitas yang diraih oleh pengusaha, sebab dengan raihan tingkat produktivitas yang tidak maksimal akan menghilang kan sejumlah besaran pendapatan yang seharusnya didapatkan pengusaha jika berada pada tingkat produktivitas yang maksimal, sehingga menyebabkan tingkat pendapatan yang didapatkan pengusaha juga tidak maksimal. Dalam pemasaran rumput laut agar petani memilih melalui saluran pemasaran II (petani-pedagang antar pulau - pedagang besar-eksportir) karena saluran pemasaran tersebut mempunyai efisiensi yang lebih tinggi serta memberikan harga dan keuntungan yang lebih tinggi (Karmila, 2011).
Upaya mencapai usahatani yang efisien sulit diwujudkan, namun pemikiran mengenai maksimasi keuntungan yang terbatas sangat berarti untuk menunjukkan bahwa petani gurem pada dasarnya juga melakukan usahatani dengan menggunakan perhitungan ekonomi. Dalam prakteknya petani kecil dalam mencapai efisiensi dan produktivitas yang diharapkan menghadapi berbagai permasalahan, baik aspek teknis (teknologi), aspek ekonomi (permodalan dan akses pasar), sosial kelembagaan (lemahnya konsolidasi kelembagaan kelompok tani), serta aspek kebijakan pemerintah yang belum kondusif untuk pengembangan usahatani (Ellis, 2003).

Istilah produktivitas secara ekonomis menggambarkan suatu perbandingan antara keluaran dan masukan (Rutkauskas and Paulaviciene, 2005). Secara konseptual, peng ukuran produktivitas suatu usaha ekonomi dapat dibedakan menjadi dua jenis yaitu produktivitas parsial atau single factor productivity dan produktivitas faktor total atau multi factor productivity. Produktivitas parsial adalah produksi rata-rata dari suatu faktor produksi yang diukur sebagai hasil bagi total produksi dan total penggunaan suatu faktor produksi. Jika faktor produksi yang digunakan lebih dari satu jenis, maka konsep produktivitas yang lebih banyak digunakan adalah produktivitas faktor total (Maulana, 2004).

Produktivitas faktor total didefinisikan sebagai rasio indeks hasil produksi dengan indeks total faktor produksi (input). Dalam prakteknya total faktor produksi biasanya diukur dalam angka indeks sehingga langsung dapat mencermikan tingkat relatif antar waktu (Maulana, 2004). Maka produktivitas total faktor produksi adalah ukuran kemampuan seluruh jenis faktor produksi sebagai satu kesatuan faktor produksi agregat dalam menghasilkan output secara keseluruhan (output agregat). Penentuan rasio indeks hasil produksi dengan indeks total faktor produksi (input) di tentukan dengan indeks efisiensi. Dengan begitu, penetuan tingkat produktivitas 
pengusaha rumput laut dapat diketahui dengan penentuan tingkat efisiensi.

Tingkat pendapatan maksimal yang dicapai petani berkaitan erat dengan efisiensi berproduksi usahatani. Proses produksi tidak efisien karena dua hal berikut: (1) karena secara teknis tidak efisien, hal ini terjadi karena ketidakberhasilan mewujudkan produktivitas maksimal; artinya per unit paket masukan (input bundle) tidak dapat menghasilkan produksi maksimal, dan (2) secara alokatif tidak efisien karena pada tingkat harga-harga masukan dan keluaran tertentu, proporsi penggunaan masukan tidak optimum disebabkan karena produk penerimaan marginal (marginal revenue product) tidak sama dengan biaya marginal (marginal cost) masukan yang digunakan. Kedua hal tersebut lebih sering dikenal sebagai efisiensi teknis dan efisiensi alokatif. Kedua tingkat efisiensi tersebut merupakan komponen dari suatu ukuran tingkat produktivitas yakni overall efficiency atau yang lebih dikenal sebagai efisiensi ekonomi. Tingkat efisiensi ekonomi suatu usaha merupakan tolok ukur penentuan tingkat produktivitas yang diraih suatu usaha (Ellis, 2003; Sumaryanto et al., 2003). Berdasarkan hal tersebut dapat dikaitkan antara produktivitas, efisiensi serta pendapa tan yaitu efisiensi merupakan tolok ukur dari tingkat produktivitas sedangkan tingkat produktivitas tersebut sangat menentukan tingkat pendapatan yang diperoleh pengusaha rumput laut dari keseluruhan sumber daya dan teknologi dalam satu set tertentu.

Meningkatnya kesejahteraan material masyarakat secara keseluruhan sehubungan dengan efisiensi, dan pertumbuhan ekonomi terjadi apabila tingkat harga sumberdaya dan output tertentu terjadi perubahan penggunaan sumberdaya dari kurang efisien menjadi lebih efisien atau terjadi peningkatan produktivitas sumberdaya sehingga dengan sumberdaya yang sama diperoleh output yang lebih besar (Ellis, 2003). Dengan begitu seiring dengan adanya selisih antara tingkat efisiensi ekonomi yang diraih pengusaha dengan tingkat efisiensi ekonomi tertinggi maka peningkatan pendapatan masih dapat dilakukan tanpa adanya realokasi sumberdaya ataupun redistribusi komoditi.

Meskipun pengusahaan antara satu dengan lainnya hampir tidak terdapat perbedaan secara teknis, namun hal ini pastinya akan berbeda antara pengusaha satu dengan yang lainnya karena terdapat perbedaan kemampuan untuk menyesuaikan dengan karakteristik alam yang sangat penting dalam usaha pengusahaan rumput laut. Penyesuaian tersebut mempengaruhi tingkat transformasi input menjadi output dan alokasi faktor produksi antar pengusaha yang sangat ditentukan oleh kemampuan manajerial pengusaha sebagai suatu Desicion Making Unit (DMU) bagi usaha budidaya rumput laut tersebut. Dengan perbedaan tersebut maka kemampu an untuk mengefisiensikan usaha rumput laut secara ekonomi akan berbeda-beda antara pengusaha.

Kapabilitas manajerial dalam aspek budidaya tercermin dalam aplikasi teknologi usahatani. Masukan apa saja yang digunakan, berapa banyak, kapan (dan berapa kali), dan dengan metode atau cara berproduksi seperti apa merupakan unsurunsur pokok yang tercakup dalam aplikasi teknologi tersebut. Pada akhirnya, kapabilitas manajerial akan tercermin dari keluaran yang diperoleh ketika hasil tanamannya sudah dipanen. Jika produksi yang diperoleh mendekati potensi maksimum dari suatu aplikasi teknologi yang terbaik (the best practiced) di suatu ekosistem yang serupa, maka dapat dikatakan bahwa petani tersebut telah mengelola usahataninya dengan efisiensi yang tinggi (Saptana et al., 2010).

Berdasarkan pengamatan empiris walaupun petani telah memiliki pengalaman panjang dalam berusahatani, namun petani tidak selalu dapat mencapai tingkat efisiensi tertinggi, hal ini disebabkan hasil yang dicapai pada dasarnya merupakan resultante bekerjanya demikian banyak faktor, baik 
yang tidak dapat dikendalikannya (eksternal) maupun yang dapat dikendalikannya (internal) (Sumaryanto et al., 2003). Faktorfaktor internal tersebut lazimnya berkaitan erat dengan kapabilitas manajerialnya dalam usahatani dan karakteristik pengusaha tercakup didalamnya yakni luas lahan, pengalaman berusahatani, jumlah anggota keluarga. Adapun faktor eksternal yang tercakup didalamnya yakni harga jual output ataupun saluran pemasaran yang pilih oleh para pengusaha rumput laut.

Determinan tersebut ada yang berasal dari dalam proses pengusahaan yang mempengaruhi kemampuan manajerial petani dan adapula yang berasal dari luar proses pengusahaan yang sifatnya sebagai faktor eksternal ataupun dalam lingkup pemasaran. Sebagaimana penelitian sebelumnya yang menyatakan bahwa kondisi sosial ekonomi, faktor demografi, karakteristik usahatani, faktor lingkungan dan faktor non fisik mempengaruhi efisiensi (Kebede, 2001). Selain itu, inefisiensi usaha dapat bersumber pada manajemen usahatani (Sutanto, 2008).

Dengan begitu, berdasarkan uraian yang telah dikemukakan maka salah satu langkah strategis untuk membantu pengusaha dalam peningkatan pendapatannya adalah dengan menganalisis tingkat efisiensi ekonomi usaha budidaya rumput laut dan mendeskripsikan secara simultan terhadap faktor-faktor non-teknis yang mempe ngaruhinya.

Kriteria efisiensi mengacu pada pendapat Farrell yang mengemukakan bahwa ukuran efisiensi terdiri dari efisiensi teknis dan efisiensi alokatif. Studi modern efisiensi dikemukakan oleh Farrel melalui paper efisiensi yang memperkenalkan metodologi untuk mengukur efisiensi ekonomi, teknis, dan alokasi. Dalam metodologi ini, Efisiensi Ekonomi (EE) adalah sama dengan produk Efisiensi Teknis (TE) dan Alloactive Efisiensi (AE). Menurut Farrell, TE dikaitkan dengan kemampuan untuk memproduksi pada isokuan perbatasan, sementara $\mathrm{AE}$ mengacu pada kemampuan untuk mempro- duksi pada tingkat output tertentu dengan menggunakan rasio biaya-masukan memini malkan. EE didefinisikan sebagai kemampuan dari suatu perusahaan untuk menghasilkan kuantitas yang telah ditentukan output pada biaya minimum untuk suatu tingkat teknologi (Dipeolu and Okinbode, 2011).

Gabungan kedua efisiensi ini disebut efisiensi ekonomi (Economic Efficiency-EE) atau disebut juga efisiensi total. Hal ini berarti bahwa produk yang dihasilkan oleh suatu perusahaan baik secara teknis maupun alokatif adalah efisien. Untuk mengilustrasikan konsep efisiensi-efisiensi tersebut, Farrell menggunakan contoh sederhana dari suatu industri yang menggunakan hanya dua input, $X_{1}$ dan $X_{2}$ untuk menghasilkan output $Y$, hal tersebut dapat dilihat pada Gambar 3.1. berikut.

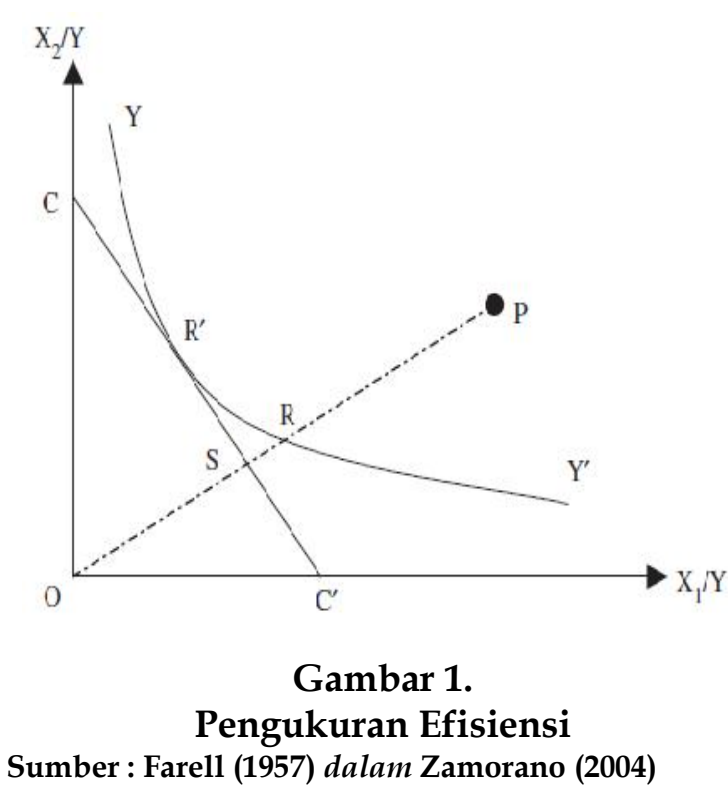

Sumber : Farell (1957) dalam Zamorano (2004)

Pada Gambar 3.1 YY adalah isoquant dan garis $\mathrm{CC}^{\prime}$ adalah garis isocost (kombinasi input yang dapat dibeli dengan anggaran yang sama). Titik $\mathrm{P}$ secara teknis tidak efisien dan titik $\mathrm{R}$ secara teknis efisien karena terletak pada isoquant, tetapi secara alokatif tidak efisien. Titik $S$ secara teknis tidak efisien tetapi secara alokatif efisien karena menempati kombinasi harga input 
yang efisien pada garis isocost CC'. Titik R' secara teknis dan alokatif efisien atau disebut juga efisien secara ekonomis. Jarak antara titik $\mathrm{S}$ dan $\mathrm{R}$ adalah besarnya biaya yang diminimalkan jika perusahaan ingin berproduksi pada titik $R^{\prime}$ yang merupakan tempat kombinasi penggunaan input yang efisien secara teknis dan alokatif (Zamorano, 2004).

Untuk menotasikan kondisi di lapangan ke dalam konsep Farrel tersebut maka dibutuhkan suatu ukuran yang mencerminkan keragaan aktual usahatani dan mencantumkan seluruh sumberdaya yang digunakan yang relevan dalam proses transformasi dan alokasi untuk mencapai tingkat efisiensi tertentu. Pendekatan yang telah dikembangkan dan diaplikasikan untuk mengukur efisiensi dengan melibatkan penggunaan fungsi batas/frontier. Penggunaan fungsi frontier tampaknya sangat beralasan karena memberikan penekanan terhadap konsep maksimalitas dan minimalitas yang terkandung di dalamnya. Pada kasus fungsi produksi selalu terdapat keterkaitan antara pengukuran efisiensi di tingkat usahatani dengan estimasi frontier produksi, hal ini terjadi karena diperlukan suatu standar untuk mengukur inefisiensi. Keterkaitan semacam ini juga terjadi pada penggunaan fungsi biaya atau fungsi keuntungan (Adiyoga, 1999 dalam Ismunandar, 2012).

Berdasarkan hal tersebut untuk menentukan batasan/frontier tersebut maka digunakan fungsi biaya untuk menghasilkan batasan/frontier terhadap tingkat efisiensi ekonomi. Dengan menggunakan batasan/ frontier tersebut, maka kinerja setiap pengu saha akan diketahui, kemampuannya terhadap batas yang seharusnya dimaksimalkan untuk memaksimalkan keuntungannya. Adapun metode pendekatan terbaik yang digunakan untuk menentukan batasan/ frontier tersebut adalah dengan pendekatan statistik stochastic. Pendekatan statistik stochastic dirasakan terbaik karena pendekatan ini turut mempertimbangkan kemungkinan-kemungkinan bahwa keragaman usahatani dapat dipengaruhi oleh faktorfaktor diluar kontrol pengelola.

Dalam model batasan/frontier stochastic, output diasumsikan dibatasi dari atas oleh suatu fungsi yakni fungsi fungsi biaya untuk efisiensi ekonomi, batasan tersebut diestimasi oleh bantuan penduga kemiripan maksimum (Maximum Likelihood Estimator). Selisih antara batasan tersebut dengan output setiap pengusaha akan menjadi suatu standar penentuan tingkat inefisiensi. Terdapat tiga alasan utama untuk mempertimbangkan the dual forms dari fungsi produksi yakni fungsi biaya ataupun fungsi keuntungan yaitu untuk merefleksikan berbagai perubahan tujuan, untuk menghitung jumlah hasil produksi, dan untuk mengsimultankan prediksi akan efisiensi teknis dan efisiensi alokatif berdasarkan kinerja rata-rata (best fit) (Coelli et al., 2005).

Salah satu keistimewaan pengukuran efisiensi ekonomi dengan menggunakan konsep stochastic frontier adalah dengan dapat ditentukannya tingkat efisiensi setiap pengusaha rumput laut. Dengan adanya variasi tingkat efisiensi antara pengusaha rumput laut satu dengan yang lainnya maka menandakan bahwa adanya pendugaan bahwa keragaan usaha dapat dipengaruhi oleh faktor-faktor didalam usaha pembudiaya rumput laut dan diluar kontrol unit produksi. Sebagaimana lazimnya dalam usaha pertanian lainnya dan juga usaha budidaya rumput laut, tingkat produksi dan tingkat biaya dipengaruhi secara langsung oleh jumlah dan jenis faktor produksi serta harga faktor produksi. Sedangkan efisiensi ekonomi sebagai tolok ukur produktivitas dipengaruhi oleh faktor yang secara tidak langsung, faktor-faktor tersebut disebut sebagai determinan efisiensi.

Menurut Ogundari (2007), pendekatan input berorientasi untuk mengukur hasil EE tiga set input: (1) set diamati, $X_{o}$, (2) set teknis efisien, XTE, dan (3) set Xee efisien secara ekonomi. Produk kotor input ini menetapkan harga vektor yang menghasilkan biaya yang diamati secara teknis efisien dan ekonomis efisien mengatur input 
masing-masing. Biaya ini dapat digunakan untuk menyusun langkah-langkah $\mathrm{TE}_{\mathrm{i}}, \mathrm{AE}_{\mathrm{i}}$ dan $E_{i}$ seperti yang ditunjukkan dengan ini.

$$
\begin{aligned}
& \mathrm{TE}_{\mathrm{i}}=\text { PXte } / \text { PXo } \\
& \mathrm{EE}_{\mathrm{i}}=\text { PXee/PXo } \\
& \mathrm{AE}_{\mathrm{i}}=\text { PXee/PXte; (i.e.,EE/TE) }
\end{aligned}
$$

Untuk mengukur efisiensi ekonomis tersebut dapat dilakukan dengan menurunkan fungsi biaya dual dari fungsi produksi Cobb-Douglas yang homogenous (Rifiana, et al., 2010). Fungsi biaya bentuk dual dari fungsi produksi frontier yang dijelaskan sebelumnya diatas secara umum dapat dituliskan demikian (Hadiana, 2007).

$$
C=f(w, y)
$$

$C$ adalah biaya minimum dan berhubungan dengan output $\mathrm{y}$, dan $\mathrm{w}$ adalah vektor harga input. Assa et al. (2011); Ogundari and Ojo (2006) menggunakan model fungsi biaya Stochastic frontier untuk memperkirakan tingkat efisiensi biaya keseluruhan ditetapkan sebagai:

$C_{i}=g\left(Y_{p} W_{i} ; a\right)+\varepsilon_{i} \quad i=1,2, \ldots n$.

di mana $\mathrm{C}_{i}$ merupakan biaya minimum yang berhubungan dengan produksi usahatani, $Y_{i}$ merupakan output yang dihasilkan, $\mathrm{W}_{i}$ mewakili vektor harga input, a merupakan parameter fungsi biaya dan ci merupakan error term yang terdiri dari dua elemen. Yaitu: Dimana $C_{i}$ merupakan total biaya produksi, $Y_{i}$ merupakan output yang di hasilkan, $P_{i}$ merupakan biaya input, a merupakan parameter fungsi biaya dan $\varepsilon_{i}$ merupakan error term yang terdiri dari dua elemen. Yaitu:

$$
\varepsilon_{\mathrm{I}}=\mathrm{V}_{\mathrm{i}}+\mathrm{U}_{\mathrm{i}}
$$

Dimana $\mathrm{V}_{i}$ adalah gangguan simetris di asumsikan identik, independen dan biasanya didistribusikan sebagai $\mathrm{N}\left(\begin{array}{ll}0, & \left.\sigma^{2} \mathrm{v}\right)\end{array}\right.$ mengingat struktur stokastik perbatasan. Komponen kedua $\mathrm{U}_{i}$ one side error term yang independen dari $\mathrm{V}_{i}$ dan terdistribusi normal sebagai $(0, \sigma u)$, yang memungkinkan produksi aktual yang lebih rendah di bawah batas tapi tanpa menghubungkan semua produksi aktual yang lebih rendah di bawah batas merupakan suatu inefisiensi.

Inefisiensi diasumsikan untuk selalu meningkatkan biaya, komponen kesalahan didahului oleh tanda-tanda positif. Efisiensi ekonomi tertentu (EE) didefinisikan sebagai rasio total biaya produksi diamati minimum $\left(C^{*}\right)$ untuk total biaya produksi aktual (C). EE mengambil nilai antara 0 dan 1 . Bentuk fungsional Cobb-Douglas digunakan dengan model penelitian yang sesuai karena alasan berikut: (a) bentuk fungsional telah digunakan dalam banyak studi empiris, khususnya, yang berkaitan dengan pengembangan pertanian Negara, (b) bentuk fungsi onal juga memenuhi kriteria untuk menjadi diri ganda yang memungkinkan pemeriksaan efisiensi ekonomi. Kemudian Ogundari et al. (2006) mengemukakan bahwa pemilihan fungsi Cobb-Douglas didasarkan pada kenyataan bahwa metodologi estimasi efisiensi membutuhkan fungsi dual seperti dalam kasus fungsi biaya di mana analisis ini didasarkan.

Hal ini sesuai dengan persamaan permintaan masukan biaya minimum. Dengan adanya informasi harga input, akan ada kemungkinan untuk mengukur efisiensi biaya perusahaan yang menjadi suatu pertimbangan. Subtitusi harga input pertanian dan kuantitas output dalam persamaan (2) menghasilkan biaya yang meminimalkan vektor masukan. Misalkan $X$ dan $X^{*}$ mewakili vektor masukan terkait dengan efisiensi teknis dan minimisasi vektor biaya input, masing-masing. Kemudian, efisiensi biaya (CE) pertanian didefinisikan sebagai rasio biaya input yang terkait dengan vektor input, $X$ dan $X^{*}$.

$$
C E=\frac{W^{\prime} X}{W^{\prime} X^{*}}
$$


Jika pengusaha meminimumkan biaya, ia akan merespon dan mengambil keputusan dalam menggunakan input sesuai dengan perubahan-perubahan biaya akibat dari perubahan harga-harga input. Sesuai dengan teori Sheppard Lemma, permintaan input adalah:

$$
\mathrm{X}_{\mathrm{i}}^{*}(\mathrm{w}, \mathrm{Q})=\frac{\partial C}{\partial W_{1}}
$$

Persamaan diatas menjelaskan bahwa turunan parsial dari fungsi biaya terhadap masing-masing harga input merupakan fungsi permintaan input kondisional $\left(\mathrm{x}_{\mathrm{i}}^{*}\right)$. Kenaikan satu rupiah harga input $\left(\mathrm{w}_{\mathrm{i}}\right)$ menyebabkan biaya meningkat sebesar $\alpha c$, ceteris paribus, dan kenaikan biaya tersebut semata-mata ditentukan penggunaan input $x_{i}$ kali kenaikan harga $\alpha w_{t}$.

Dengan menggunakan data harga input dan output di tingkat produsen yang disubtitusikan ke dalam persamaan permintaan input diatas, akan diperoleh tingkat penggunaan input yang secara ekonomis efisien $\left(\mathrm{x}_{\mathrm{e}}\right)$. Selanjutnya kedua vektor ukuran penggunaan input tersebut $\left(x_{i}\right)$ dan $\left(x_{e}\right)$ digunakan untuk menghitung biaya produksi yang secara teknis efisien $\left(x_{t}^{\prime} w\right)$ dan biaya yang secara ekonomis efisien $\left(\mathrm{x}_{\mathrm{e}}{ }^{\mathrm{w}} \mathrm{w}\right)$. Dengan menerapkan teori Sheppard Lemma, dari fungsi biaya frontier diatas dapat ditentukan tingkat penggunaan input yang optimal, sehingga diperoleh ukuran biaya yang paling efisien $\left(\mathrm{x}_{\mathrm{t}}, \mathrm{w}\right)$ yang dapat dijadikan dasar pembanding ukuran inefisiensi teknis. Menurut Ureta dan Rieger (1991) dalam Hadiana (2007), dengan pengukuran penggunaan input di tingkat produsen, maka dari vektor penggunaan input tersebut $\left(x_{a}\right)$ dapat diperoleh biaya aktual $\left(x_{a}{ }^{\prime} w\right)$. Selanjutnya dari ketiga ukuran biaya tersebut dapat dijadikan dasar untuk mengukur indeks efisiensi teknis (ET) dan efisiensi ekonomis (EE) sebagai berikut:

$$
\begin{aligned}
& \mathrm{ET}=\left(\mathrm{x}_{\mathrm{t}}{ }^{\prime} \mathrm{w}\right) /\left(\mathrm{x}_{\mathrm{a}} \mathrm{w}\right) \\
& \mathrm{EE}=\left(\mathrm{x}_{\mathrm{e}}{ }^{\prime} \mathrm{w}\right) /\left(\mathrm{x}_{\mathrm{a}} \mathrm{w}\right)
\end{aligned}
$$

Efisiensi alokatif diturunkan dari kedua persamaan diatas yaitu:

$\mathrm{EA}=\left(\mathrm{x}_{\mathrm{e}}{ }^{\prime} \mathrm{w}\right) /\left(\mathrm{x}_{\mathrm{t}} \mathrm{W}\right)$

Dalam bentuk persamaan, fungsi biaya frontier dapat dinyatakan sebagai berikut:

$\mathrm{C}_{\mathrm{i}}=\left(\mathrm{w}_{\mathrm{i}}, \mathrm{y}_{\mathrm{i}}\right) \beta_{\mathrm{i}}+\left(\mathrm{v}_{\mathrm{i}}+\mathrm{u}_{\mathrm{i}}\right)$

$\mathrm{C}_{\mathrm{i}}$ adalah logaritma biaya produksi dari peternak ke-i

$\mathrm{w}_{\mathrm{i}}$ adalah vektor dari $\mathrm{k} \times 1$ variabel bebas harga input yang sudah ditransformasikan kedalam bentuk logaritma

$\mathrm{y}_{\mathrm{i}}$ adalah vektor dari variabel output dalam logaritma

$\beta_{\mathrm{i}}$ adalah vektor parameter biaya produksi

$\mathrm{V}_{\mathrm{i}}$ adalah variabel acak yang diasumsikan menyebar normal $\mathrm{N}\left(0, \sigma_{\mathrm{v}}{ }^{2}\right)$

$\mathrm{u}_{\mathrm{i}}$ adalah variabel acak non negatif yang berhubungan dengan efisiensi biaya didalam proses produksi, diasumsikan berdistribusi sisi kanan kurva normal (half normal) $\mathrm{N}\left(0, \mathrm{\sigma}_{\mathrm{u}}{ }^{2}\right)$.

Dalam fungsi biaya frontier, parameter $\mathrm{u}_{\mathrm{i}}$ merupakan ukuran besarnya kelebihan biaya produksi dari biaya frontier. Jika asumsi efisiensi alokatif dipenuhi, maka $\mathfrak{u}_{i}$ adalah ukuran inefisiensi ekonomi, dicapainya efisiensi teknis menunjukkan bahwa produksi tersebut secara ekonomis juga efisien.

Untuk kasus fungsi biaya frontier, jika variabel terikat (biaya produksi, C) dinyatakan dalam bentuk logaritma, maka ukuran inefisiensi adalah eksponen $u_{i}$.

$$
\mathrm{EE}=\operatorname{Exp}\left(\mathrm{u}_{\mathrm{i}}\right)
$$

Jika variabel terikat tidak ditransformasikan kedalam bentuk logaritma maka ukuran inefisiensi ekonomi adalah:

$\left.\mathrm{EE}=\left(\left(\mathrm{w}_{\mathrm{i}}, \mathrm{y}\right) \beta_{\mathrm{i}}+\mathrm{u}_{\mathrm{i}}\right) /\left(\left(\mathrm{w}_{\mathrm{i}}, \mathrm{y}\right) \beta_{\mathrm{i}}\right)\right)$

Moradi et. al. (2013) mengemukakan bahwa analisis stocastic frontier juga dapat dilakukan pada data panel pada sebuah produsen melalui periode waktu. Juga kita mengasumsikan bahwa inti deterministik 
dari biaya stochastic frontier mengambil bentuk Cobb Douglas. Dengan demikian model biaya forntier sebagai berikut.

Ln $E_{i t}=\beta_{0}+\beta_{y} \ln y_{i t} \sum_{n} \beta_{n} \ln w_{n i t}+v_{n i t}+u_{i}$ (15)

Dimana $\mathrm{v}_{\text {it }}$ merupakan error term, merupakan invarian time efisiensi biaya, dan $\Sigma \mathrm{n} \beta \mathrm{n}$ $=1$ menjamin homogenitas derajat dari model biaya frontier pada harga input. Maka asumsi berikut merupakan komponen kesalahan dalam model biaya stochastic frontier.

i. $v_{i} \sim$ iid $N\left(0, \sigma^{2} v\right)$

ii. $\mathrm{u}_{\mathrm{i}} \sim$ iid $\mathrm{N}\left(0, \sigma^{2} \mathrm{v}\right)$

iii. $v_{i}$ dan $u_{i}$ terdistribusi secara independent

Penentuan tingkat efisiensi ekonomi diikuti dengan variabel-variabel sosial ekonomi yang dimasukkan dalam model untuk menunjukkan pengaruh mereka pada efisiensi ekonomi para petani. Sebagai dan seperti parameter skalar yang akan diestimasi. Varians dari kesalahan acak $\sigma^{2} \mathrm{v}$ dan bahwa dari biaya inefisiensi efek $\sigma^{2} u$ dan varians keseluruhan model $\sigma$. Perkiraan untuk semua parameter dari fungsi biaya frontier stokastik dan model inefisiensi secara simultan. Estimasi parameter Maximum likelihood fungsi biaya untuk menghasilkan indeks efisiensi ekonomi diperoleh dengan menggunakan perangkat lunak FRONTIER 4.1 (Ogundari, et. al., 2007; Azizi and Moghaddasi, 2012).

Menentukan sumber-sumber inefisiensi teknis bukan hanya memberi informasi pada sumber potensial inefisiensi tetapi juga menghasilkan kebijakan untuk diimple mentasikan atau dihilangkan guna meningkatkan efisiensi secara keseluruhan (Kalirajan (1991) dalam Saptana et. al. (2010)). Salah satu kebijakan penting adalah bagaimana meningkatkan produktivitas secara nyata melalui terobosan-terobosan inovasi teknologi yang lebih maju melalui kegiatan penelitian dan pengembangan serta adaptasinya di tingkat produsen.

Ada dua pendekatan untuk menguji sumber efisiensi teknis (technical efficiency/ TE) dan sekaligus sumber ketidakefisienan. Pertama merupakan prosedur dua langkah dan yang ke dua prosedur satu langkah (simultan). Pertama, merupakan prosedur dua langkah. Langkah pertama, meliputi estimasi nilai efisiensi (atau efek inefisiensi) untuk pengusaha secara individu, sesudah mengestimasi fungsi produksi frontier. Kedua, melakukan estimasi model regresi di mana nilai efisiensi (inefisiensi yang diestimasi) dinyatakan sebagai fungsi variabel sosio-ekonomi yang diasumsikan mempengaruhi inefisiensi. Metode lain adalah prosedur satu langkah, di mana efek inefisiensi dalam frontier stokastik yang dibuat model dalam bentuk variabel yang dianggap relevan dalam menerangkan inefisiensi produksi seperti dalam model (Coelli et al., 2005).

Prosedur dua langkah telah digunakan untuk meneliti sumber TE dalam berbagai studi (Hallam dan Machado, 1996; Kalirajan, 1991; Parikh et al., 1995; Kebede, 2001 dalam Ismunandar, 2012) yang memilih half normal distribution sebagai model analisis untuk penentuan efisiensi dan mengemukakan bahwa penggunaan prosedur satu langkah (truncanted normal distribution) menghasilkan hasil analisis yang ekstrim jika dibandingkan dengan penggunaan prosedur dua langkah (half normal distribution) yang menghasilkan hasil analisis yang lebih moderat, serta model half normal distribution mempunyai estimasi yang signifikan untuk parameter dan variannya. Dengan begitu, pada penelitian ini menggunakan model half normal distribution.

Pengujian estimasi inefisiensi biaya sesuai dengan distribusi teoritis dari perkiraan inefisiensi, mengingat asumsi awal yaitu distribusi half normal untuk syarat inefisiensi dalam model stochastic frontier. Hal ini harus ditententukan mengingat bahwa tentang tidak adanya justifikasi prioritas terhadap penggunaan asumsi distri- 
busi dalam syarat inefisiensi dalam pendekatan stochastic frontier. Sebelumya Aigner menetapkan asumsi eksponensial ataupun asumsi distribusi half normal pada syarat inefisiensi. Namun, tidak ada alasan untuk pemaksaan pemilihan distribusi modus null. Spesifikasi bentuk fungsional yang lebih umum seperti normal truncaned. Pada akhirnya, baru-baru ini, dapat disimpulkan bahwa asumsi distribusi adalah yang sangat penting, karena adanya perbedaan dalam estimasi parameter dengan masing-masing asumsi (Fried et al., 2008).

Salah satu aspek untuk memperhitungkan adalah bahwa distribusi perkiraan inefisiensi tidak bisa diharapkan bertepa tan dengan distribusi yang diasumsikan pada inefisiensi biaya. Dalam pengertian ini, Wang dan Schmidt (2009); Bhandari (2011) telah mengembangkan distribusi perkiraan inefisiensi dengan asumsi distribusi half normal dan normal truncanted. Meskipun beberapa pendapat sebelumnya membuktikan bahwa tidaklah sesuai untuk mengasumsikan distribusi normal setengah untuk estimasi inefisiensi ketika inefisiensi didistribusikan sebagai setengah normal, kecuali varians kesalahan acak yang sangat kecil. Wang et. al. (2011) mengusulkan tes untuk memeriksa goodness of fit dari distribusi diasumsikan.

Gallego et al. (2012) mengemukakan hasil penelitiannya yaitu asumsi distribusi half normal sebagai syarat penerapan inefisiensi dalam model stochastic frontier sebagai asumsi yang tepat melalui uji goodness of fit antara kepadatan teoritis estimasi biaya inefisiensi dan distribusi perkiraan biaya inefisiensi unit dipilih untuk sampel.

\section{METODE PENELITIAN}

Penelitian ini menggunakan metode survei yang dibangun dengan analisis yang menggunakan pendekatan secara kuantitatif dalam ruang lingkup kajian ekonomi produksi yang objek penelitiannya adalah pengusaha rumput laut. Penelitian ini ditekankan untuk mengetahui kemampuan pengusaha dalam upaya pengelolaan usaha dengan tujuan utamanya untuk memaksimalkan keuntungan.

Populasi dalam penelitian terdiri dari seluruh pengusaha rumput laut yang membudidayakan rumput laut pada daerah penelitian. Lokasi penelitian dilaksanakan pada 3 Kecamatan di Kabupaten Muna yakni Kecamatan Towea, Kecamatan Duruka, dan Kecamatan Kusambi. Pemilihan lokasi penelitian tersebut dengan pertimbangan bahwa ketiga Kecamatan tersebut merupakan sentra produksi rumput laut tertinggi pada tahun 2012.

Teknik penentuan ukuran sampel sesuai yang dikemukakan oleh (Riduan, 2007) sebagai berikut:

$$
\mathrm{n}=\frac{\mathrm{N}}{\mathrm{N} \cdot \mathrm{d}^{2}+1}
$$

dimana:

$\mathrm{n}=$ jumlah sampel seluruhnya

$\mathrm{N}=$ jumlah populasi seluruhnya

$\mathrm{d}^{2}=$ presisi yang ditetapkan, sebesar $10 \%$

Jenis data yang dianalisis dalam penelitian ini adalah data kerat silang (cross section) pada satu periode produksi. Diperoleh ukuran sampel sebanyak 86 pengusaha. Teknik pengambilan sampel pengusaha rumput laut dilakukan dengan menggunakan metode acak proporsional. Sedang kan penentuan jumlah sampel untuk masing-masing kecamatan dilakukan dengan cara proporsional dan penarikan sampelnya dilakukan dengan teknik acak sederhana (simple random sampling).

Penentuan tingkat produktivitas pengu saha rumput laut diukur dengan menggunakan metode produktivitas faktor total atau multi factor productivity (Maulana, 2004). Metode produktivitas faktor total atau multi factor productivity ini dipilih karena pengusahaan rumput laut menggunakan lebih dari satu faktor produksi sehingga dalam penentuan produktivitas wajib melibatkan pengukuran pada tiap-tiap pengunaan faktor produksi untuk menentukan rasio indeks hasil produksi dengan indeks total faktor produksi (input) dalam 
satu nilai indeks.

Adapun untuk penentuan indeks tingkat produktvitas setiap pengusaha rumput laut tersebut, dilakukan dengan pengukuran efisiensi ekonomi yang sebagaimana dikemukakan Farrell. Mengingat bahwa pengukuran efsiensi ekonomi dengan meng gunakan fungsi biaya sejalan dengan konsep metode produktivitas faktor total atau multi factor productivity karena dapat melibatkan seluruh faktor produksi. Pemili han penentuan efisiensi ekonomi/overall economic efficiency berdasarkan tiga kelebihan yang dapat didapatkan dalam analisis ini yaitu dapat merefleksikan berbagai peru bahan tujuan, untuk menghitung jumlah hasil produksi, dan untuk mengsimultankan prediksi akan efisiensi teknis dan efisiensi alokatif berdasarkan kinerja ratarata (best fit) (Coelli et al., 2005).

Teknik analisis untuk mengukur efisiensi ekonomis dapat dilakukan dengan menurunkan fungsi biaya dual dari fungsi produksi Cobb-Douglas yang homogenous. Efsiensi ekonomi (EE) didefinisikan sebagai rasio antara total biaya produksi aktual (C) dengan biaya total produksi minimum yang diobservasi $\left(C^{*}\right)$, seperti terlihat pada persamaan dibawah ini (Ogundari dan Ojo, 2006; Kurniawan et al., 2008; Ismunandar, 2012).

$E E_{\mathrm{i}}=\frac{C}{C^{*}}=\frac{\exp \left[C_{i}\left(y_{i}, p_{i}, \beta\right)+v_{i}+u_{i}\right]}{\exp \left[C_{i}\left(y_{i}, p_{i}, \beta\right)+v_{i}\right]}=\exp \left(u_{i}\right)$

Tingkat efisiensi ekonomi diestimasi dengan menggunakan Fungsi biaya Stochastic Frontier dan dengan opsi Error Components Model karena memilih menggunakan model half normal distribution untuk mengestimasi tingkat efisiensi ekonomi usahatani budidaya rumput laut. Ukuran efisiensi berdasarkan pendekatan stochastic frontier, dilakukan dengan terlebih dahulu menetapkan fungsi biaya dual stochastic frontier. Pendugaan parameter dari fungsi dibawah ini menggunakan metode Maximum likelihood estimation (MLE), dengan perangkat lunak FRONTIER versi 4.1 yang persamaan nya yaitu $C_{i}=C\left(w_{i}, y_{i}, \beta\right)+v_{i}+u_{i}$, maka jika diubah ke bentuk logaritma natural sebagai berikut:

$\ln C_{\mathrm{i}}=\beta_{\mathrm{o}}+\beta_{1} \ln \left(\mathrm{w}_{\mathrm{i} 1}\right)+\beta_{2} \ln \left(\mathrm{w}_{\mathrm{i} 2}\right)+\beta_{3} \ln \left(\mathrm{w}_{\mathrm{i} 3}\right)+$ $\beta_{4} \ln \left(\mathrm{w}_{\mathrm{i} 4}\right)+\mathrm{v}_{\mathrm{i}}+\mathrm{u}_{\mathrm{i}}$

\section{Keterangan:}

$\mathrm{C}_{\mathrm{i}}=$ Biaya Produksi usaha pembibitan dalam satu siklus (Rp)

$\mathrm{w}_{1}=$ Harga bibit dalam satu siklus ( $\mathrm{Rp} / \mathrm{Kg}$ satuan produksi)

$\mathrm{w}_{2}=$ Harga Transportasi dalam satu siklus ( $\mathrm{Rp} / \mathrm{kg}$ satuan produksi)

$\mathrm{w}_{3}=$ Harga Bahan Bakar dalam satu siklus ( $\mathrm{Rp} / \mathrm{Kg}$ satuan produksi)

$\mathrm{w}_{4}=$ Harga Tenaga Kerja satu siklus ( $\mathrm{Rp} / \mathrm{Kg}$ satuan produksi)

$\mathrm{Y}=$ Jumlah produksi pembudidaayaan rumput laut dalam satu siklus $(\mathrm{kg})$

$\beta_{\mathrm{o}}=$ Konstanta

$\beta_{\mathrm{i}}=$ Parameter peubah input tidak tetap yang diduga

$\mathrm{v}_{\mathrm{i}}=$ variabel acak yang merupakan simpangan atau deviasi (galat) akibat kekeliruan pengukuran dan atau faktor-faktor lain.

$\mathrm{u}_{\mathrm{i}}=$ variabel acak non negatif, variabel ini berhubungan dengan koefisien inefisiensi biaya pada masingmasing unit pengamatan.

Nilai efisiensi dari persamaan tersebut di atas diistilahkannya sebagai overall economics efficiency/Efisiensi Ekonomi ( $\left.\mathrm{EE}_{\mathrm{i}}\right)$ pada masing-masing unit pengamatan $i$. $\mathrm{C}^{*}$ adalah biaya pada kondisi ideal dimana dicapai efisiensi (full efficient), sedangkan $\mathrm{C}$ adalah biaya aktual berdasarkan hasil pengamatan, imbangan kedua ukuran ini akan menentukan koefisien inefisiensi. Jika $\mathrm{C}_{\mathrm{i}}{ }^{*}=\mathrm{C}_{\mathrm{i}}$ maka tidak ada efek inefisiensi $\left(\mathrm{u}_{\mathrm{i}}=0\right)$ pada unit pengamatan, atau dengan kata lain dicapai biaya relatif terendah (full efficient) dan mempunyai indeks $\mathrm{EE}_{\mathrm{i}}=1$, jika $\mathrm{C}_{\mathrm{i}}{ }^{*}<\mathrm{C}_{\mathrm{i}}$ maka terjadi inefisiensi $\left(u_{i}>0\right)$, dan indeks $E_{i}>1$. 
Nilai koefisien inefisiensi berkisar antara satu dan tak terhingga (Coelli et al., 2005).

Keragaman dari indeks/nilai efisiensi ekonomi merupakan pertanda bahwa terdapat perbedaan tingkat produktifitas antar pengusaha rumput laut. Perbedaan tingkat produktifitas tersebut diduga dipengaruhi oleh beberapa faktor yang dapat menjadi faktor determinan yang berpengaruh terhadap produktifitas. Adapun faktor yang berpengaruh terhadap tingkat produktifitas bagi usaha budidaya rumput diestimasi dengan menetukan pengaruh beberapa faktor tertentu terhadap nilai efisiensi ekonomi tiap-tiap pengusaha rumput laut. Adapun faktor yang berpengaruh terhadap efisiensi ekonomi bagi usaha budidaya rumput diestimasi dengan menggunakan analisis regresi disajikan dengan formulasi persamaan dalam penelitian sebagai berikut:

$$
\begin{aligned}
\mathrm{EE}_{\mathrm{i}}= & \delta_{0}+\delta_{1} \mathrm{Z}_{1}+\delta_{2} \mathrm{Z}_{2}+\delta_{3} \mathrm{Z}_{3}+\delta_{4} \mathrm{Z}_{4}+\delta_{5} \mathrm{Z}_{5}+ \\
\delta_{6} \mathrm{Z}_{6}+\varepsilon & (18) \\
\mathrm{EE}_{\mathrm{i}}= & \text { Tingkat Efisiensi Ekonomi } \\
\mathrm{Z}_{1}= & \text { Luas Lahan (Ha) } \\
\mathrm{Z}_{2}= & \text { Pengalaman berusaha rumput laut } \\
& \text { (Tahun) } \\
\mathrm{Z}_{3}= & \text { Jumlah Anggota Keluarga (Orang) } \\
\mathrm{Z}_{4}= & \text { Harga Jual Hasil Rumput Laut } \\
& \text { (Rupiah) } \\
\mathrm{Z}_{5}= & \text { Dummy Saluran Pemasaran } \\
0= & \text { Pedagang Pengumpul Lokal (PPL) } \\
1 & =\text { Pedagang Antar Pulau (PPA) } \\
\delta_{0}= & \text { Konstanta } \\
\delta_{i}= & \text { Parameter peubah input tidak tetap } \\
\varepsilon= & \text { yang diduga } \\
\varepsilon= & \text { Unsur sisa }
\end{aligned}
$$

Untuk menguji suatu model regresi yang ditaksir dengan menggunakan metode estimasi Maximum Likelihood memenuhi persyaratan yang telah ditetapkan mengenai parameter model regresi yang ditaksir maka digunakan pengujian Likelihood Ratio Test (LR test). LR test dihitung dengan menggunakan rumus berikut:
$\mathrm{LR}=-2\left(\mathrm{~L}_{0}-\mathrm{L}_{1}\right) \sim X_{m}^{2}$

Keterangan:

$\mathrm{L}_{0}=$ nilai $\log$ likelihood function dalam model regresi tanpa pembatasan

$\mathrm{L}_{1}=$ nilai log likelihood function dalam model regresi dengan pembatasan

$\mathrm{m}=$ jumlah pembatasan

Dalam pengujian kita membandingkan nilai $\mathrm{X}^{2}$ yang diperoleh dari rumus tersebut terhadap nilai kritis $\mathrm{X}^{2}$ pada taraf kepercayaan tertentu. Apabila nilai $X_{m}^{2}$ lebih besar dari pada nilai $X^{2}$ yang diperoleh dari tabel critical value maka nilai seluruh parameter sama dengan nol $\left(\mathrm{H}_{0}: \beta_{1}=\beta_{2}=\ldots \beta_{\mathrm{i}}=\right.$ $0)$ dapat ditolak (Sitepu dan Sinaga, 2006). Pengujian LR test terhadap model yaitu jika $\mathrm{H}_{1}$ diterima apabila LR test $>\mathrm{X}^{2}$ pada taraf kepercayaan tertentu berarti variabel bebas secara serempak berpengaruh signifikan terhadap variabel terikat. $\mathrm{H}_{0}$ diterima apabila LR test $<\mathrm{X}^{2}$ pada taraf kepercayaan tertentu maka maka berarti variabel bebas secara serempak tidak berpengaruh signifikan terhadap variabel terikat (Zajc, 2006 ; Gallego et. al., 2012).

$\mathrm{H}_{0}: \beta_{1}=\beta_{2}=\ldots \beta_{\mathrm{i}}=0$

$\mathrm{H}_{1}: \beta_{1} \neq \beta_{2} \neq \ldots \beta_{\mathrm{i}} \neq 0$

Untuk menyamakan pemahaman dan persepsi terhadap istilah peubah-peubah yang digunakan maka perlu dikemukakan definisi operasional dari peubah-peubah yang digunakan dalam penelitian ini beserta pengukurannya, sebagai berikut:

1. Produktivitas adalah adalah kemampuan perusahaan untuk menghasilkan sejumlah barang sejumlah faktor produksi tertentu dalam rasio antara output dan input, dalam penelitian ini proses produksi menggunakan bermacam-macam input maka rasio antara jumlah output dengan semua inputnya dinamakan produktivitas seluruh faktor produksi. Pendugaan produktivitas seluruh faktor produksi dapat diukur 
dengan menggunakan ukuran indeks efisiensi ekonomi.

2. Efisiensi Ekonomi yaitu suatu tingkatan dari peternak untuk menghasilkan produksi maksimal pada rasio kombinasi harga yang memiliki biaya paling kecil, dimana usaha tidak dapat lagi menghasilkan sejumlah hasil produksi pada sejumlah faktor produksi tertentu. Efisiensi ekonomi disebut juga sebagai overall economic efficiency merupakan efisiensi total yang mencakup efisiensi teknis dan efisiensi alokatif.

3. Biaya Produksi usaha rumput laut yakni biaya variabel atau biaya yang langsung berhubungan dengan besar kecilnya produksi $(Y i)$ yang dikeluarkan oleh setiap pengusaha dalam satu siklus usaha yang berasal dari penjumlahan dari seluruh total pengeluaran dalam kegiatan penyediaan bibit, transportasi serta penggunaan bahan bakar yang dihitung dalam satuan rupiah.

4. Harga Bibit dalam hal ini adalah harga per satuan kilogram produksi yang dikeluarkan oleh pengusaha rumput untuk mendapatkan sejumlah bibit rumput laut.

5. Harga transportasi dalam hal ini adalah harga rata-rata per satuan kilogram produksi yang dikeluarkan oleh pengusaha rumput dalam kebutuhan transpor tasi selama masa produksi pada berbagai jenis transportasi yang digunakan pengusaha.

6. Harga Bahan Bakar dalam hal ini adalah harga rata-rata per satuan kilogram produksi yang dikeluarkan oleh pengusaha rumput pada berbagai jenis bahan bakar yang digunakan selama masa produksi.

7. Harga Tenaga Kerja dalam hal ini adalah harga rata-rata yang dihitung per satuan kilogram produksi yang dikeluarkan oleh pengusaha dalam pembayaran upah tenaga kerja.

8. Luas Lahan diukur yaitu luasan usaha rumput laut berdasarkan jarak benam bibit $\mathrm{x}$ panjang bentangan $\mathrm{x}$ banyaknya bentangan dalam satuan hektar.

9. Pengalaman berusaha rumput laut yaitu lamanya waktu yang telah dilalui pengusaha rumput laut sejak pertama kali mulai berusaha hingga saat penelitian dilakukan, yang dinyatakan dalam tahun.

10. Jumlah Anggota Keluarga yaitu jumlah anggota keluarga yang terdapat di dalam struktur rumah tangga seorang pengusaha rumput laut yang diukur dalam satuan orang.

11. Harga Jual Hasil Rumput Laut yaitu harga jual rumput laut pada tingkat produsen yang merupakan hasil transaksi antara seorang pengusaha dengan pedagang (baik pengumpul besar ataupun pedagang antar pulau) yang dinyatakan dengan satuan rupiah.

12. Saluran Pemasaran seluruh bagian dari pemasaran yang terdiri dari lembaga pemasaran tertentu yang berperan dalam distribusi hasil produksi yang mem punyai jalur dan ruang lingkup pem saran tertentu.

\section{ANALISIS DAN PEMBAHASAN}

Hasil dan pembahasan dari penelitian ini dibahas dalam tiga bagian. Pertama, akan dibahas secara deskripsi usahatani budidaya rumput laut yang dilakukan di derah penelitian. Kemudian, analisis deskripsi statistik ini diikuti dengan analisis hasil estimasi fungsi biaya frontier dan efisiensi ekonomi usahatani budidaya rumput laut, serta faktor-faktor yang mempengaruhi efisiensi ekonomi tersebut.

Statistik deskripsi untuk semua peubah yang digunakan dalam pendugaan fungsi biaya frontier stokastik disajikan pada Tabel 1. Tabel ini menunjukkan rentang jumlah produksi yang cukup besar dengan ratarata sebesar 547,33 Kg yang menunjukkan bahwa jumlah produksi cukup variatif. Nilai rata-rata total biaya sebesar 3.276. 147,04 dengan rentang nilai minimum dan maksimum yang cukup berbeda mengisyaratkan bahwa biaya yang dikeluarkan 
antara pengusaha juga bervariasi. Pada peubah harga input dapat diketahui bahwa harga yang paling besar dikeluarkan oleh pengusaha dalam membudidayakan rumput lautnya yakni pada harga bibit yang mempunyai rata-rata yang lebih besar dari harga-harga input lainnya yakni sebesar $\mathrm{Rp}$ 2.809,66,-, hal ini menunjukkan bahwa harga bibit dapat mengakibatkan perubahan yang lebih drastis pada besarnya total biaya.

Tabel 1.

Deskripsi Statistik Usahatani Budidaya Rumput Laut, 2012

\begin{tabular}{lccccc}
\hline \hline Peubah & N & Rerata & $\begin{array}{c}\text { St. } \\
\text { Deviasi }\end{array}$ & Minimum & Maksimum \\
\hline Jumlah Produksi (Kg) & 86 & 547,33 & 133,04 & 318,00 & 989,00 \\
Total Biaya (Rp) & 86 & $327.6147,04$ & $643.451,97$ & $2.088 .437,84$ & $5.684 .074,95$ \\
$\begin{array}{l}\text { Harga Bibit (Rp/Kg } \\
\text { satuan produksi) }\end{array}$ & 86 & $2.809,66$ & 369,12 & 1651,28 & $3.486,06$ \\
$\begin{array}{l}\text { Harga Transportasi } \\
\text { (Rp/Kg satuan produksi) }\end{array}$ & 86 & 37,01 & 28,62 & 9,62 & 111,35 \\
$\begin{array}{l}\text { Harga Bahan Bakar } \\
\text { (Rp/Kg satuan produksi) }\end{array}$ & 86 & 68,18 & 23,00 & 29,17 & 131,15 \\
$\begin{array}{l}\text { Harga Tenaga kerja } \\
\text { (Rp/Kg satuan produksi) }\end{array}$ & 86 & $2.382,31$ & 391,17 & $1.460,92$ & $3.192,01$ \\
\hline
\end{tabular}

Sumber : Hasil Penelitian, 2012

Tabel 2.

Hasil Dugaan Untuk Parameter Fungsi Biaya Frontier Stokastik Usaha Budidaya Rumput Laut, 2012

\begin{tabular}{lcccc}
\hline \hline \multirow{2}{*}{ Variabel } & \multicolumn{2}{c}{ OLS } & \multicolumn{2}{c}{ MLE } \\
\cline { 2 - 5 } & $\begin{array}{c}\text { Koefisien } \\
\text { (Std.Error) }\end{array}$ & t-ratio & $\begin{array}{c}\text { Koefisien } \\
\text { (Std.Error) }\end{array}$ & t-ratio \\
\hline Konstanta & $\begin{array}{c}4.6440102^{* * *} \\
(0.32214134)\end{array}$ & 14.416064 & $\begin{array}{c}4,6058450^{* * *} \\
(1,0000000)\end{array}$ & 4,6058450 \\
& $0.41332129^{* * *}$ & 11.527497 & $\begin{array}{c}0.41332129^{\text {tn }} \\
(1,0000000)\end{array}$ & 0.41332129 \\
Harga Bibit & $(0.035855249)$ & & $0.017830324^{\text {tn }}$ & 0.017830324 \\
Harga & $0.17830324^{* * *}$ & 2.8151203 & $(1,0000000)$ & \\
Transportasi & $(0.0063337699)$ & & $0.0021602681^{\text {tn }}$ & 0.0021602681 \\
Harga Bahan & $0.21602681^{\text {tn }}$ & 17800353 & $(1,0000000)$ & \\
Bakar & $(0.012136097)$ & & $0.22308300^{\text {tn }}$ & 0.22308300 \\
Harga & $0.22308300^{* * *}$ & \multirow{2}{*}{6.4822334} & $(1,0000000)$ & $0.83804066^{\text {tn }}$ \\
Tenaga kerja & $(0.034414527)$ & & $(1,0000000)$ & 0.83804066 \\
Jumlah & $0.83804066^{* * *}$ & 38.955830 & $0.0027238024^{\text {tn }}$ & 0.0027238024 \\
Produksi & $(0.021512586 \mathrm{E})$ & & $(1,0000000)$ & \\
$\sigma^{2}$ & & & $0.84000000^{\text {tn }}$ & 0.84000000 \\
& & & $(1,0000000)$ & \\
Y & & & $11,563268^{* * *}$ & \\
LR test & & & & \\
\hline
\end{tabular}

Sumber : Data terolah (2011) dengan FRONTIER 4.1. 
Keterangan:

*** berpengaruh nyata pada taraf kepercayaan 99 persen

** berpengaruh nyata pada taraf kepercayaan 95 persen

* berpengaruh nyata pada taraf kepercayaan 90 persen

tn berpengaruh tidak nyata

Hasil dugaan model fungsi biaya frontier stokastik yang dijelaskan dalam persamaan (17) disajikan dalam Tabel 2.

Dari Tabel ini, peubah harga bibit, harga transportasi, harga tenaga kerja dan jumlah produksi menunjukkan pengaruh yang sangat nyata dan bertanda hubungan positif terhadap total biaya usahatani budidaya rumput laut sedangkan peubah harga bahan bakar meskipun menunjukkan tanda hubungan yang positif juga namun tidak berpengaruh terhadap total biaya usahatani budidaya rumput laut. Tanda hubungan positif antara peubah dalam model terhadap total biaya usahatani budidaya rumput laut merupakan hal yang sejalan dengan teori yakni naiknya harga input maka akan mengakibatkan total biaya akan meningkat pula. Pada Tabel 2. Juga menunjukan bahwa peubah Jumlah Produksi merupakan peubah yang mempunyai nilai elastisitas tertinggi yakni 0,83804066. Ini berarti bahwa faktor produksi ini mempunyai pengaruh yang paling besar terhadap produksi.

Pengujian terhadap persamaan fungsi biaya yang menggunakan metode Maximum Likelihood Estimator untuk memenuhi per- syaratan dapat diketahui dengan mengguna kan pengujian LR test. Hasil pengujian LR test pada Tabel 2. menunjukkan nilai 11,563268 , sedangkan nilai kritis $X^{2}$ yang diperoleh dari tabel critical value $\mathrm{X}^{2}$ dengan jumlah pembatasan $=1$ pada taraf kepercayaan 99 persen yaitu sebesar 5,412. Dengan membandingkan nilai LR test $(11,563268)$ dan nilai kritis $X_{1}^{2}(5,412)$, maka dapat diketahui bahwa LR test $>X_{1}^{2}$ pada taraf kepercayaan 99 persen berarti variabel bebas secara serempak berpengaruh signifikan terhadap variabel terikat dengan begitu keputusan terhadap pengujian adalah menolak $\mathrm{H}_{0}$ dan menerima $\mathrm{H}_{1}\left(\mathrm{H}_{1}: \beta_{1} \neq \beta_{2} \neq\right.$ $\ldots \beta_{\mathrm{i}} \neq 0$ ) yang berarti bahwa model fungsi biaya frontier stokastik sudah baik. Pada tabel 3. dibawah menunjukkan ringkasan sebaran tingkat efisiensi ekonomi yang diduga dari fungsi biaya stokastik frontier.

Tabel 3 menunjukkan ringkasan tingkat efisiensi ekonomi yang diduga dari fungsi biaya stokastik frontier.

Tingkat efisiensi ekonomi dari pengusahaan rumput laut di daerah penelitian

Tabel 3.

Hasil Tabulasi Sebaran Tingkat Efisiensi Ekonomi Pada Usaha Budidaya Rumput Laut, 2012

\begin{tabular}{ccc}
\hline \hline Tingkat Efisiensi Ekonomi & Jumlah & Persentase (\%) \\
\hline $0,800-0,849$ & 1 & 1,16 \\
$0,850-0,899$ & 2 & 2,33 \\
$0,900-0,949$ & 10 & 11,63 \\
$0,950-0,999$ & 73 & 84,88 \\
\hline Jumlah & 86 & 100,00 \\
\hline Maksimum & 0.9939 & \\
Minimum & 0.8453 & \\
Rata-Rata & 0.9634 & \\
\hline
\end{tabular}

Sumber : Data terolah (2011) dengan FRONTIER 4.1. 
sudah tergolong tinggi, yakni berada pada rentang dari yang terendah sebesar 0,8453 (84,53 persen) dan tertinggi sebesar 0,9939 (99,39 persen). Secara keseluruhan performansi pencapaian tingkat efisiensi ekonomi yang diraih oleh pengusaha di daerah penelitian digambarkan dengan nilai ratarata tingkat efisiensi ekonomi yakni sebesar 0,9634 (96,34 persen). Tingkat efisiensi ekonomi sebesar 0,9634 (96,34 persen) menggambarkan bahwa secara rata-rata pengusaha dapat mencapai produktivitasnya hing ga 96 persen dari faktor-faktor produksi yang telah dikorbankannya. Hal ini berarti bahwa secara keseluruhan rata-rata tingkat keberhasilan pengusaha rumput laut untuk meminimumkan biaya produksi yang telah dicapai dalam adalah sekitar 96 persen dari frontier-nya yakni tingkat biaya yang paling minimum yang seharusnya dapat dicapai dengan alokasi berbagai sumberdaya yang dimilikinya dalam aplikasi sistem teknis pengusahaan ternak yang terbaik (the best practiced).

Dari analisis diperoleh bahwa lebih dari 80 persen pengusaha rumput laut di daerah penelitian sudah beroperasi pada tingkat efisiensi yang lebih dari 95 persen. Adapun sisanya yakni sebesar 13 persen yang hanya berproduktivitas dibawah 95 persen hingga 80 persen. Meskipun belum ada pembandingnya tingkat efisiensi ekonomi yang diraih oleh pengusaha di daerah penelitian dalam membudidayakan rumput laut dapat dikatakan sangat tinggi.

Tabel 4.

Hasil Dugaan Untuk Determinan Tingkat Efisiensi Ekonomi Usaha Budidaya Rumput Laut, 2012

\begin{tabular}{lccc}
\hline \hline \multicolumn{1}{c}{ Peubah } & Koefisien & (Std.Error) & t-ratio \\
\hline Konstanta & $0.419^{\mathrm{tn}}$ & 0.255 & 1.639 \\
Luas Lahan & $0.008^{\mathrm{tn}}$ & 0.005 & 1.578 \\
Pengamalan berusahatani & $-0.003^{*}$ & 0.002 & -1.749 \\
Jumlah anggota keluarga & $-0.001^{\mathrm{tn}}$ & 0.001 & -.891 \\
Harga jual rumput laut & $0.059^{* *}$ & 0.027 & 2.186 \\
Dummy Saluran penjualan & $0.079^{* *}$ & 0.037 & 2.121 \\
\hline
\end{tabular}

Sumber : Data terolah (2011) dengan SPSS 16.0.

Keterangan:

*** berpengaruh nyata pada taraf kepercayaan 99 persen

** berpengaruh nyata pada taraf kepercayaan 95 persen

* berpengaruh nyata pada taraf kepercayaan 90 persen

tn berpengaruh tidak nyata

Determinan efisiensi ekonomi pada usahatani budidaya rumput laut pada pada daerah penelitian disajikan pada Tabel 4 . Luas lahan dimasukkan untuk mengetahui pengaruh luas lahan terhadap efisiensi ekonomi yang diasumsikan semakin luas lahan akan meningkatkan jam kerja yang harus dipenuhi sehingga berimbas pada biaya tenaga kerja. Namun demikian, hasil analisis menunjukkan bahwa luas lahan tidak berpengaruh nyata terhadap efisiensi ekonomi. Kesimpulan yang sama juga didapatkan pada peubah Jumlah anggota keluarga pengusaha, yakni menunjukkan jumlah ang gota keluarga tidak mempengaruhi efisiensi ekonomi, hal ini mengindikasikan bahwa alokasi biaya tenaga kerja yang dikeluarkan oleh pengusaha tidak dipengaruhi meskipun terdapat adanya tenaga kerja potensial yang dapat membantu usahatani budidaya 
rumput laut. Selain itu, dapat juga disebabkan bahwa jam kerja yang dibutuhkan pada luasan lahan yang dibudidayakan masih dapat dipenuhi oleh keluarga sendiri pada masing-masing pengusaha.

Adapun determinan yang berpengaruh terhadap tingkat efisiensi ekonomi yang di capai pengusaha yakni pengalaman berusaha tani yang hanya berpengaruh pada taraf kesalahan 10 persen. Tanda yang didapatkan dari keberpengaruhan peubah pengala man berusahatani adalah negatif, tanda ini tidak sesuai dengan harapan yakni positif. Berdasarkan hal tersebut maka hal ini mengindikasikan bahwa pengusaha yang pengalamannya belum lama mempunyai kemampuan dalam menginterpretasikan teknologi rumput laut yang tidak berbeda bahkan lebih baik dari pengusaha yang pengalamannya lebih lama yakni baik dalam kombinasi maupun alokasi faktor produksi dari pada tersebut secara baik. Salah satu alasan yang dapat menjelaskan hal ini adalah usahatani budidaya rumput laut merupakan usahatani musiman yang dapat dilakukan tiga kali setahun dan paling sedikit sekali setahun. Dengan begitu pengusaha yang baru mempunyai sedikit pengalaman akan mampu dan berpeluang besar untuk dapat menyesuaikan cara-cara membudidayakan rumput laut oleh pengusaha yang sudah berpengalaman. Sebab, pengusaha rumput laut di Kabupaten Muna mendapatkan pengetahuan cara membudidayakan rumput yang baik dari pengusaha lain yang lebih berpengalaman sehingga penyesuaian terhadap usaha rumput laut oleh pengusaha yang baru dapat berlangsung cepat.

Peubah harga jual rumput laut dan saluran pemasaran menunjukkan keberpengaruhan yang nyata terhadap tingkat efisiensi ekonomi pada taraf kesalahan 5 persen. Harga jual rumput laut merupakan faktor ekternal di luar manajemen usaha budidaya rumput laut yang merupakan dorongan bagi pengusaha untuk berproduksi dengan tujuan untuk selalu berusaha memaksimalkan pendapatannya. Hasil ana- lisis pada Tabel 4. menunjukkan bahwa harga jual rumput laut berpengaruh positif terhadap efisiensi ekonomi rumput laut, maka semakin tinggi pengusaha mendapatkan harga jual maka akan semakin tinggi pula tingkat efisiensinya. Pengusaha yang mendapat harga jual yang tinggi akan selalu termotivasi untuk berusaha meningkatkan produktivitasnya karena pengusaha akan selalu berusaha memaksimalkan pendapatannya. Sedangkan pada pengusaha yang mendapatkan harga jual yang lebih rendah kurang termotivasi untuk meningkatkan produktivitasnya. Kurangnya motivasi pengusaha tersebut disebabkan oleh pemikiran pengusaha yang merasa bahwa perubahan harga untuk menjadi lebih tinggi yang sulit terjadi sebagai akibat struktur pemasaran yang tertutup.

Pengujian variabel dummy saluran pemasaran menunjukkan keberpengaruhan variabel yang nyata pada taraf kesalahan 5 persen. Dengan begitu, saluran pemasaran yang digunakan pengusaha untuk memasar kan hasil usahatani rumput laut memberikan pengaruh terhadap pengusaha dalam meningkatkan produktivitas. Saluran pemasaran yang ada pada daerah penelitian terdiri dari saluran pedagang pengumpul lokal dan pedagang pengumpul antar pulau. Perbedaan saluran pemasaran mengakibatkan perbedaan harga sehingga dengan begitu akan mengakibatkan perbedaan motivasi untuk mencapai produktivitas yang lebih tinggi.

\section{SIMPULAN SARAN}

Penelitian ini telah menduga model fungsi biaya frontier stokastik yang sekaligus menduga efisiensi ekonomi pengusahaan rumput laut yang dilakukan oleh pengusaha di Kabupaten Muna. Hasil dugaan fungsi biaya berdasarkan Ordinary Least Square menunjukkan semua peubah mempunyai tanda yang sesuai dengan harapan dan hampir semua peubah dalam model berpengaruh nyata hanya peubah Harga Bahan Bahar saja yang tidak berpengaruh. 
Sedangkan, pada hasil dugaan fungsi biaya berdasarkan Maximum Likelihood Estimators menunjukkan semua peubah mempunyai tanda yang sesuai dengan harapan hanya saja secara parsial peubah tidak berpengaruh namun secara bersama-sama perubah berpengaruh nyata.

Tingkat efisiensi ekonomi yang dicapai pengusaha berbeda-beda pada rentang anta ra 80 persen hingga 99 persen, namun secara umum tingkat efisiensi ekonomi pengu saha di daerah penelitian sudah tergolong tinggi. Hasil analisis faktor determinan yang mempengaruhi efisiensi ekonomi menunjukkan bahwa peubah harga jual rumput laut dan dummy saluran pemasaran berpengaruh pada taraf kesalahan 95 persen, serta peubah pengalaman berusahatani yang hanya berpengaruh pada taraf kesalahan 10 persen serta menunjukkan tanda yang tidak sesuai harapan. Adapun peubah luas lahan dan jumlah anggota keluarga tidak berpengaruh terhadap tingkat efisiensi ekonomi usahatani budidaya rumput laut.

Implikasi dari temuan diatas adalah tingkat efisiensi ekonomi yang dicapai oleh pengusaha di daerah penelitian yang sudah tergolong tinggi tersebut yakni secara ratarata berada pada tingkat 96 persen mengidikasikan bahwa sebenarnya peluang untuk meningkatkan produktivitas yang sudah cukup tinggi ini semakin kecil karena senjang antara tingkat produktivitas ratarata yang diraih oleh pengusaha dengan tingkat produktivitas maksimum yang dapat dicapai dengan alokasi dan kombinasi input yang terbaik (the best practiced farm) itu cukup sempit. Dengan begitu, peningkatan jumlah produksi untuk memenuhi permintaan pasaran sebenarnya hanya dapat dilakukan dengan peningkatan skala usaha. Selain itu, determinan yang berpengaruh pada tingkat efisiensi ekonomi memberikan suatu informasi bahwa perlu adanya pembenahan yang melibatkan campur tangan pemerintah untuk mengatasi sistem pemasaran rumput laut karena dengan sistem pemasaran yang baik akan memberikan dampak yang baik terhadap tingkat harga yang diterima pengusaha yang pada akhirnya akan meningkatkan produktivitas pengusaha tersebut.

\section{DAFTAR PUSTAKA}

Assa, M. M., A. K. Edriss, and G. C. Matchaya. 2011. Cost efficiency, Morishima, Allen-Uzawa and CrossPrice elasticities among Irish potato farmers in Dedza district, Malawi. International Journal of Economic Sciences and Applied Research 6(1): 59-73.

Azizi, K and R. Moghaddasi. 2012. Potato Production Efficiency: Evidence from Firoozkuh, Iran. Middle-East Journal of Scientific Research 11(10): 1439-1442.

Bhandari, A.K. 2011. On The Distribution Of Estimated Technical Efficiency In Stochastic Frontier Models : Revisited. International Journal of Business and Economics 5(10): 69-80.

Clenia, M. 2008. Analisis Rasio Biaya Sumberdaya Domestik Usaha Budidaya Rumput Laut Di Indonesia. Jurnal Bisnis dan Ekonomi (JBE) 15(1): 31 - 38.

Coelli, T., D. S. P. Rao, C. J. O'Donnell and G. E. Battese. 2005. An Introduction To Efficiency and Productivity Analysis, 2nd ed. Springer Science Bussiness Media Inc. New York USA.

Dipeolu, A. O. dan S. O. Okinbode. 2011. Technical, Economic and Allocative Effciencies of Pepper Production in South-West Nigeria: A Stochastic Frontier Approach. Journal of Economics and Rural Development 17(1): 24-33

Dunningham, J. and Attack. T. 2011. Seaweed Farming In Scotland: Aquaculture of macroalgae. Journal of Applied Phycology (16): 355-368.

Ellis, F. 2003. Peasant Economics (Petani Gurem : Rumah Tangga Usahatani dan Pembangunan Pertanian). Diterjemahkan oleh Adi Sutanto dkk. Bayu Media dan UMM Press. Malang.

Fried, H.O., C. A. K. Lovell and S. S. Schmidt. 2008. The Measurement of 
Productive Efficiency and Productivity Growth. Oxford University Press.

Gallego, J. C. G., J. G. Garcia, and M.C.P. Carceles. 2012. Appropriate Distribution of Cost Inefficiency Estimates as Predictor of Financial Instability. Estudi Os De Economí A.Ap Licada 30 (3): 1-12.

Hadiana, M. H. 2007. Dampak Faktor Eksternal Kawasan Terhadap Efisiensi Usaha Ternak Sapi Perah : Survey Pada Usaha Ternak Sapi Perah Di Kabupaten Bandung). Disertasi. Program Pascasarjana Universitas Padjajaran. Bandung.

Ismunandar, D. B. 2012. Analisis Efisiensi Ekonomi Stocahastic Frontier Pada Usaha Ternak Ayam Ras Pedaging Di Kota Kendari Provinsi Sulawesi Tenggara. Tesis. Fakultas Peternakan Universitas Brawijaya. Malang.

Karmila, W. S. 2011. Analisis Pemasaran Dan Resiko Pelaku Bisnis Rumput Laut Di Kabupaten Muna. Tesis. Universitas Haluoleo.

Kurniawan A. Y., S. Hartoyo dan Y. Syaukat. 2008. Analisis Efisiensi Ekonomi dan Daya Saing Usahatani Jagung Pada Lahan Kering Di Kabupaten Tanah Laut Kalimantan Selatan. Forum Pascasarjana 31(2): 93-103.

Kronen, M., 2010. Socio-economic Dimensions of Seaweed Farming in Solomon Islands. Secretariat of the Pacific Community (SPC). Aquaculture Division Food and Agricultural Organization (FAO).

Maulana, M. 2004. Peranan Luas Lahan, Intensitas Pertanaman dan Produktivitas sebagai Sumber Pertumbuhan Padi Sawah di Indonesia 1980-2001. Jurnal Agro Ekonomi 22(1): 74-95.

Moradi, E., M. Pahlavani, A. Akbari and H.M. Bashrabadi. 2013. Comparative Analysis of Stochastic Frontier Partially Non-Parametric and Stochastic Frontier Parametric Methods Case Study: Measuring Cost Efficiency in Wheat Production in Iran. International Journal of Agricultural Management \& Development (IJAMAD) 3(2): 123-130.
Ogundari K. 2007. Technical, Allocative and Economic Efficiency of Upland Rice armers in Nigeria: A Stochastic Frontier Approach. The Empirical Economics Letters 6(6): 537-543.

Ogundari, K and S. O. Ojo. 2006. An Examination of Technical, Economic and Allocative Efficiency of Small Farm: The Case Study of Cassava Farmers in Osun State Nigeria. Journal of Central European Agriculture 3(7): 423432.

Ogundari, K., S. O. Ojo and I.A. Ajibefun. 2006. Economies of Scale and Cost Efficiency in Small Scale Maize Production: Empirical Evidence from Nigeria. Journal Social Science 13(2): 131136

Rutkauskas, J. And E. Paulaviciene. 2005. Concept of Productivity in Service Sector. Engineering Economics, Influence Of Quality Management Of The Country's Economy 3(43): 29-34.

Premalatha. M., 2011. Phytochemical Charac terization And Antimicrobial Efficiency Of Seaweed Samples, Ulva fasciata and haetomorpha antennina. International Journal of Pharma and Bio Sciences 2(1): 288-293.

Riduwan. 2007. Metode dan Teknik Menyusun Tesis. Alfabeta Bandung.

Rifiana, E., Rahmawati, dan K. Wilda. 2010. Efisiensi Teknis Dan Ekonomis Usahatani Padi Sawah Lahan Pasang Surut Di Kabupaten Banjar Kalimantan Selatan. Agroscientiae 17(3): 128-133.

Saptana, A. Daryanto, H. K. Daryanto, dan Kuntjoro. 2010. Analisis Efisiensi Teknis Produksi Usahatani Cabai Merah Besar Dan Perilaku Petani Dalam Meng hadapi Risiko. Jurnal Agro Ekonomi 28 (2): $153-188$.

Sitepu, K. R. dan B. M. Sinaga. 2006. Aplikasi Model Ekonometrika : Estimasi, Simulasi, dan Peramalan. Program Studi Ilmu Ekonomi Pertanian Sekolah Pascasarjana Institut Pertanian Bogor. Bogor.

Sumaryanto, Wahida dan M. Siregar. 2003. Determinan Efisiensi Teknis Usahatani 
Padi di Lahan Sawah Irigasi. Jurnal Agro Ekonomi 21(1): 72-96.

Sutanto, A. 2008. Efisiensi Usaha Ternak Sapi Perah. Disertasi. Program Pascasar jana Fakultas Pertanian Universitas Brawijaya. Malang.

Wang, W.S. and P. Schmidt. 2009. On The Distribution Of Estimated Technical Efficiency In Stochastic Frontier Models. Journal of Econometrics (148): 3645 .
Wang, W. S., C. Amsler and P. Schmidt. 2011. Goodness Of Fit Test In Stochastic Frontier Models". Journal of Productivity Analysis 35(2): 95-118.

Zamorano, L.R.M., 2004. Economic Efficiency And Frontier Techniques. Journal Of Economic Surveys 18(1): 35-46

Zajc, P. 2006. A Comparative Study Of Bank Efficiency In Central And Eastern. Europe: The Role Of Foreign Ownership. 